tion of the natural sciences commenced; he quickly formed the acquaintance and friendship of Dr. Wm. Smith, who at that time resided at Scarborough, and also of Mr. William Bean and Dr. Lycett.

For several years he was known only as a diligent collector of the varied objects yielded by the coast of that part of Yorkshire, more especially of the recent shells, and he never ceased to add to and improve his collection of British Mollusca until, at his death, they had become, with a single exception (that of Dr. J. Gwyn Jeffreys), the finest collection of British shells known. About the same time (1837) the discovery by Mr. Bean of the considerable Oolitic flora in the shore-beds of Gristhorpe Bay and the publication of his specimens by Lindley and Hutton in their Fossil Flora of Great Britain, had an important influence upon the mind of so enthusiastic a young man as Mr. Leckenby, and materially aided in directing his attention to Geology and Palzontology. In the pursuit of the latier science it became his especial object to acquire the finest possible specimens, or, to use his own expression, "he loved to see nature with clean face and hands." His fine museum of fossils was transferred during these later years to the Woodwardian Museum at the University of Cambridge. He mado several contributions to the pages of this Magazine, and also to the Quarterly Journal of the Geological Society of London, vols. xv. xix. and xx.

His genial and hospitable disposition won for him a large circle of friends both in Scarborough and London. The progress of the fatal disease to which he succumbed was rapid, and dates only from September, 1876.

\title{
JAMES BRYCE, ESQ., M.A., LL.D., F.G.S.
}

BonN 1806. DIED 1877.

By a deplorable accident Science has lost a most able geologist through the death of Dr. James Bryce, which occurred in the pass of Inverfarigaig, near Foyers, whilst on a geological excursion. He had sallied forth alone, hammer in hand, to examine the rocks in the pass, and whilst pursuing his researches on the top of the cliff he must have inadvertently stepped upon a loose piece of rock, which giving way beneath him, he was precipitated to the foot of the cliff, where, three hours later, his lifeless body was found by two gamekeepers.

James Bryce, son of the Rev. James Bryce, Presbyterian minister, was borm at Kalleague, near Coleraine, in the north of Ireland, October, 1806. The greater part of his early education he received at home; but he subsequently went to the University of Glasgow, where he graduated, having specially distinguished himself in Greek, and carried off, among other honours, the Blackstone prize. After leaving College, he acted as mathematical master in the Belfast Academy, until, in 1846, he was appointed to superintend the Mathematical and Geographical Department of the High School, Glasgow. There he spent the greater part of his life, diligently discharging his daily duties and earnestly endeavouring to promote the teaching of science in schools when that was not so popular as 
now. In recognition of his services in this and other capacities. his Alma Mater in 1855 conferred the degree of LL.D. Three years ago he retired from scholastic work, and came to reside in Edinburgh, where, as in the West, his genial disposition, not less than his intellectual activity and varied acquirements, soon gained him a wide circle of friends. Prominent for many years among Scotch educationists, Dr. Bryce took an active part in founding the Educational Institute, of which he was President in 1852. In 1874 he was President of the Association of Higher Class Public Schoolmasters; and within the last few months he acted as secretary to the committee for securing the continuance of the Scotch Education Board. His contributions to educational literature were numerous, but to the general public he was perhaps better known as an indefatigable geologist. When quite a young man, he contributed many papers to scientific journals upon geological subjects, and in 1834 he became a Fellow of the Geological Society of London. When resident in Belfast, he carefully investigated the geology of Antrim, and particularly of the Giants' Causeway, and these researches, the results of which were published from time to time, threw not a little light on the character of basaltic formations. After removing to Glasgow, he devoted much attention to Arran, and in due time produced an excellent work on the geology of that remarkable island, now in its second edition. He made another important contribution to the London Geological Society on the rocks of Skye and Raasay. In Glasgow, Dr. Bryce took a warm interest in the proceedings of the Philosophical Society, of which he was President for two years. As convener of the British Association's Committee on Earthquakes, he conducted experiments at Comrie, regarding which interesting reports were made. During the three years he resided in Edinburgh, he was assiduous in attendance at the meetings of various scientific societies. Of the Royal Society he was a fellow and councillor; and of the Geological Society a fellow and senior Vice-President. Dr. Bryce, it may be also mentioned, was editor of a Cyclopædia of Physical Geography. For several years he has been working at the geology of the North West Highlands, to which he made many excursions. He was a keen and intelligent observer of geological facts; and outside the family circle seemed never happier than when travelling, hammer in hand, through a district which promised to reward research. It is a melancholy coincidence, that it had been intended to ask Dr. Bryce to lead the next excursion of the Inverness Field Club to the very glen in which he has so suddenly closed an active and useful career.-The Weekly Scotsman, July 14th, 1877.

\section{MISCEILAINEOUS.}

Dixox's Grology of Sussex. 4to. 1850, pp. 454, with 60 Woodeuts and 44 Plates. - This fire work, published after Mr. Frederick Dixon's death, under the able editorship of Professor Owen, C.B., assisted by Professors Thos. Bell, F.R.S., Edward Forbes, F.R.S., Mr. Wm. Lonsdale, F.R.S., Mr. James De Carle Sowerby, and Sir Philip Grey Egerton, Bart., M.P., F.R.S., is, we understand, after an interval of twenty-seven years, to see a second edition, prepared by Professor T. Rupert Jones, F.R.S., F.G.S.; assisted by Professor Owen, C.B., and numerous other geological and pulieontological friends. To be published by Wr. J. Smith, Brighton. 